\title{
The Federal Sentencing Guidelines: Adopting Clear and Convincing Evidence as the Burden of Proof
}

\author{
Richard Husseini†
}

\section{INTRODUCTION}

In 1984 Congress passed the Sentencing Reform Act (the "Act") ${ }^{1}$ in response to the widely held view that defendants who committed similar crimes, under similar circumstances, were receiving grossly disproportionate sentences in federal courts. ${ }^{2}$ The Act established the Federal Sentencing Commission (the "Commission") to promulgate mandatory sentencing guidelines (the "Guidelines") for federal judges. ${ }^{3}$ After long debates, the Commission promulgated the Guidelines, which took effect in November 1987.

For drug and money crimes, ${ }^{5}$ the Guidelines require a trial judge to make, at sentencing, an independent determination of the amount of contraband involved in the transaction. Additionally, the trial judge must determine whether certain aggravating or mitigating circumstances exist. The Guidelines are silent, however, as to what standard of proof the trial judge should apply in determining the actual amount of drugs or money involved or in determining whether aggravating or mitigating circumstances exist.

$\dagger$ B.S. 1988, The University of Dallas; J.D. Candidate 1991, The University of Chicago.

1 Sentencing Reform Act of 1984, Pub L No $98-473$, 98 Stat 1988, codified at 18 USC $\S \S 3551-3742$ (1988) and 28 USC $\S \$ 991-98$ (1988).

2 United States Sentencing Commission, Federal Sentencing Guidelines Manual ch 1 at 2 (West, 1990) ("Guidelines Manual"). See also Mistretta $v$ United States, 488 US 361 (1989); Comprehensive Crime Control Act of 1983, S Rep No 98-225, 98th Cong, 1st Sess 41 (1983). References to chapter 1 of the Guidelines Manual are to the official introduction. All other references use section numbers.

3 Rep No 98-225 at 63 (cited in note 2).

- To avoid constitutional challenge as an ex post facto law, courts applying the Guidelines sentence a defendant based upon the sentencing regime in effect at the time of the commission of the crime. Thus, the Guidelines only apply to crimes committed after November 1, 1987. If, however, the Guidelines result in a more favorable sentence than the preGuidelines' regime, then they will apply to crimes committed on or before that date. Guidelines Manual $\$ 10.1$ (cited in note 2).

${ }^{3}$ See, for example, id at $\S \S 2 \mathrm{~B} 1.1-2 \mathrm{~B} 1.4,2 \mathrm{~B} 5.1-2 \mathrm{~B} 5.4,2 \mathrm{D} 1.1-2 \mathrm{D} 3.4$. 
Supplementary sources indicate that this silence is intentional. ${ }^{\circ}$ Courts addressing the issue have acknowledged the silence of the Guidelines and have adopted preponderance of the evidence as the standard of proof. ${ }^{7}$ This Comment argues that preponderance is not the proper standard; instead, judges should use clear and convincing evidence as the standard of proof when applying the Guidelines.

Section I explains the Guidelines' basic structure, demonstrates that a judge is not limited to the quantities of drugs or money proven at trial in sentencing a defendant, and shows that the Guidelines do not prescribe any standard of proof. Section II examines the constitutionality of using a preponderance standard to resolve disputes over the amount of contraband or over the presence of any aggravating or mitigating factors, and concludes that under current Supreme Court jurisprudence it is not clear whether preponderance satisfies due process. Section III argues that, because of this ambiguity, a general due process analysis must be employed to determine the appropriate standard of proof under the Guidelines. This analysis supports adopting a clear and convincing standard.

\section{Structure of the Guidelines}

\section{A. Real versus Charge Offense Sentencing}

The Guidelines' stated goals are honesty, uniformity, and proportionality in sentencing. ${ }^{8}$ Implementing a system that met these goals proved quite difficult for the Commission. Two competing visions of the Guidelines had to be balanced: charge offense sentencing and real offense sentencing. ${ }^{9}$ Charge offense sentencing imposes sentences based solely "upon the conduct that constitutes the elements of the offense with which the defendant was charged and of which he was convicted." 10 Real offense sentencing considers "the

\footnotetext{
- See text at notes 33-35.

' See, for example, United States v Koonce, 884 F2d 349 (8th Cir 1989). See text at note 36 .

Guidelines Manual ch 1 at 2 (cited in note 2).

- For a thorough treatment of how the Commission resolved this conflict in the Guidelines, see Stephen Breyer, Federal Sentencing Guidelines and the Key Compromises upon Which They Rest, 17 Hofstra L Rev 1 (1988). See also Charles J. Ogeltree, Jr., The Death of Discretion? Reflections on the Federal Sentencing Guidelines, 101 Harv L Rev 1938 (1988); Stanley A. Weigel, The Sentencing Reform Act of 1984: A Practical Appraisal, 36 UCLA L Rev 83 (1988).

${ }^{10}$ Guidelines Manual ch 1 at 5 (cited in note 2).
} 
actual conduct in which the defendant engaged regardless of the charges for which he was indicted or convicted."11

The Commission rejected a real offense system, but it did not adopt a pure charge offense system either. In some instances the Guidelines dictate that the trial judge is to consider aspects of the defendant's conduct not formally proven at trial. Two examples are determining the amount of contraband and identifying any aggravating or mitigating circumstances for drug and money related crimes. $^{12}$

B. Calculating the Adjusted Base Offense Level for Drug and Money Crimes

A trial judge considers two factors in sentencing convicted defendants: the particular crime and the criminal history of the defendant. ${ }^{13}$ Under the Guidelines, the sentencing range for a given crime/criminal history combination is very narrow, ${ }^{14}$ and a judge may depart from this prescribed range only in limited circumstances. ${ }^{15}$

The Guidelines provide matrices listing the appropriate sentencing range for a defendant, based on the particular crime and the defendant's criminal history. To apply the Guidelines' matrices, the court must convert the particular offense into a numerical value, referred to as the "adjusted base offense level." The adjusted base offense level has two components: the "base offense level" and "adjustments" to that level. The base offense level is a numerical value assigned to the particular federal crime. ${ }^{16}$ Adjustments upward or downward depend on the existence of specific

11 Id.

${ }^{22}$ Id at $\S 1 \mathrm{B1}$.3. This is the Guidelines' "relevant conduct" provision. As the next section explains, this provision dictates to the trial judge what evidence to consider in determining, for sentencing purposes, the actual amount of drugs or money involved in the crime.

1s Id at § 1B1.1. See also 18 USC § 3551. To calculate the criminal history category for a particular defendant, the Guidelines assign points to the defendant's prior convictions based primarily on the length of prior imprisonment. A judge may not include in his calculations crimes committed many years ago. The total points determine the criminal history category. For the purposes of this Comment, the criminal history category has little importance. For further reference, see Guidelines Manual $\S 4 \mathrm{~A}, 4 \mathrm{~B}$.

14 Specifically, "the maximum of any range cannot exceed the minimum by more than the greater of 25 percent or six months." Id, ch 1 at 1 (citation omitted).

1s "[T] $T$ he new sentencing statute permits a court to depart from a guideline-specified sentence only when it finds 'an aggravating or mitigating circumstance ... that was not adequately taken into consideration by the Sentencing Commission . . ," Id, ch 1 at 6 (citations omitted).

16 See id at $\S \S 1 B 1.1-1 B 1.2$. 
factors listed in the Guidelines. ${ }^{17}$ For example, if a defendant accepts responsibility for his actions, the court is to adjust his base offense level downward..$^{18}$ Or, if a defendant is the leader or organizer of the criminal activity, ${ }^{19}$ or has knowledge of the extreme vulnerability of his victim, ${ }^{20}$ then the court is to adjust upward.

For drug and money crimes, the quantity of the contraband determines the base offense level. ${ }^{21}$ Two basic methods of determining the amount of contraband are possible. The first resembles a charge offense method: the judge determines the level based upon the amount of contraband specified in the count on which the defendant was found guilty. The second resembles a real offense method: the judge makes an independent finding, at sentencing, of the quantity of drugs or money involved. The Guidelines dictate that the judge use the second method, and courts considering the issue have unanimously interpreted the Guidelines this way. ${ }^{22}$

To better understand this issue, it is necessary to consider the interrelationship between two provisions of the Guidelines. If a trial court convicts a defendant of a crime that is within a specifically defined subset of crimes, $\S 3 \mathrm{D} 1.2$ provides for the aggregation

17 This description oversimplifies the Guidelines. Actually, there are three components: the base offense level, specific offense characteristics, and adjustments to the base offense level. Adjustments in the technical sense apply to factors that are mitigating or aggravating circumstances for all federal crimes. Specific offense characteristics are mitigating or aggravating circumstances unique to a particular crime. For theoretical purposes these are the same; the Comment treats them together for discussion and denotes them collectively as "adjustments."

${ }^{18}$ Guidelines Manual $\$ 3 E 1.1$ (cited in note 2). This Comment does not discuss adjustments that lower the sentence of the defendant. Such adjustments are not themselves free from controversy; case law consistently has held that the defendant bears the burden of establishing a mitigating factor to adjust downward his base offense level. See, for example, United States v Urrego-Linares, 879 F2d 1234 (4th Cir 1989).

19 Guidelines Manual § $3 \mathrm{~B} 1.1$ (cited in note 2).

20 Id at $\S 3 A 1.1$.

21 See, for example, id at $\S \S 2 B 5,2 D 1$.

22 See, for example, United States $v$ Blanco, 888 F2d 907 (1st Cir 1989); United States v Guerra, 888 F2d 247 (2d Cir 1989); United States v Ryan, 866 F2d 604 (3d Cir 1989); United States $v$ Williams, 880 F2d 804 (4th Cir 1989); United States v Taplette, 872 F2d 101 (5th Cir 1989); United States v Sailes, 872 F2d 735 (6th Cir 1989); United States v White, 888 F2d 490 (7th Cir 1989); United States v Koonce, 884 F2d 349 (8th Cir 1989); United States v Shorteeth, 887 F2d 253 (10th Cir 1989); United States $v$ Scroggins, 880 F2d 1204 (11th Cir 1989). In United States $v$ Restrepo, 883 F2d 781 (9th Cir 1989), the Ninth Circuit held that the judge must determine the base offense level solely by looking at the quantity of drugs stated in the count on which the defendant was found guilty beyond a reasonable doubt. However, the Ninth Circuit has withdrawn its first opinion in Restrepo, 896 F2d 1228, and issued a new opinion agreeing with the approach of the other circuits, 903 F2d 648 (9th Cir 1990). 
of the crimes for sentencing. ${ }^{23}$ The rationale behind this provision is that if the crimes are so interrelated that they constitute a single harm, it is inequitable to sentence the defendant separately for each offense. ${ }^{24}$ Drug and money crimes qualify for aggregation under $\S 3 \mathrm{D} 1.2$; if a court convicts a defendant of two drug crimes, the court will add the quantities involved to determine the base offense level.

Under $\S 1 B 1.3$, if the convicted defendant's crime would qualify for aggregation under $\S 3 \mathrm{D} 1.2$, a court is to consider all actions part of the same course of conduct in determining the base offense level. ${ }^{25}$ That the defendant has not been convicted beyond a reasonable doubt for the other conduct at issue is not relevant. The Guidelines' Commentary to $\S 1 \mathrm{~B} 1.3$ addresses this precise situation:

Subsection (a)(2) provides for consideration of a broader range of conduct with respect to one class of offenses .... The distinction is made on the basis of $\S 3 \mathrm{D} 1.2(\mathrm{~d})$, which provides for grouping together (i.e., treating as a single count) all counts charging offenses of a type covered by this subsection. However, the applicability of subsection (a)(2) does not depend upon whether multiple counts are alleged. . . . Similarly, in a drug distribution case, quantities and types of drugs not specified in the count of conviction are to be included in determining the offense level if they were part of the same course of conduct or part of a common scheme or plan as the count of conviction. ${ }^{26}$

${ }^{23}$ The relevant part of the rule reads: "All counts involving substantially the same harm shall be grouped together into a single Group." Guidelines Manual § 3D1.2 (cited in note 2). The specifically defined subset of crimes includes "[c]ounts [that] are grouped together if the offense level is determined largely on the basis of the total amount of harm or loss, the quantity of a substance involved, or some other measure of aggregate harm ...." Id at $\S 3 \mathrm{D} 1.2(\mathrm{~d})$.

24 An example given in the Guidelines is a defendant's forging and uttering the same check. Not grouping the two counts together would result in the defendant's receiving two punishments for what is essentially one crime. Id at $\S 3 \mathrm{D} 1.2$, application note 3 , example (1).

25 Specifically, the section states:

Relevant Conduct (Factors that Determine the Guideline Range)

(a)... the base offense level where the guideline specifies more than one base offense level, . . . (2) solely with respect to offenses of a character for which § $3 D 1.2(d)$ would require grouping of multiple counts, all such acts and omissions that were part of the same course of conduct or common scheme or plan as the offense of conviction. . . . Id at $\S 1 \mathrm{~B} 1.3$.

${ }^{26}$ Guideline; Manual, Background Commentary to $\S 1 \mathrm{~B} 1.3$ (cited in note 2) (emphasis added). 
As long as the drugs or money are part of the same course of conduct, the trial judge considers the entire quantity involved, regardless of whether this quantity was proven beyond a reasonable doubt at trial. ${ }^{27}$

\section{The Guidelines Do Not Prescribe a Standard of Proof}

Thus, at sentencing, a judge must make an independent finding of the quantity of contraband involved in the defendant's offense. In determining adjustments, the judge relies on circumstances of the defendant's crime not proven beyond a reasonable doubt at trial..$^{28}$ The question of the appropriate standard of proof thus arises. While they do not specify the standard of proof trial courts should apply in determining the base offense level or adjustments, the Guidelines do provide a procedure for arriving at the proper sentence. A probation officer first completes a presentence report, containing the calculation of the appropriate Guidelines' sentence. ${ }^{29}$ For example, if the defendant is convicted of a drug crime, the probation officer will determine the quantity of drugs involved in the same course of conduct. Likewise, based on his investigation (including the trial court record), the probation officer determines whether the defendant led the activity or any other facts that might cause an adjustment to the base offense level.

While the presentence report indicates the probation officer's suggested sentence, both the government and the defendant can dispute any of the probation officer's findings. The Guidelines provide that:

When any factor important to the sentencing determination is reasonably in dispute, the parties shall be given an adequate

${ }^{27}$ The Sentencing Commission's Trainer's Manual provides a specific example. The government initially charges a defendant with two drug counts, later dismisses one of the counts, and the defendant pleads guilty to the other. If the drugs alleged in the dismissed count were part of the same course of conduct as the offense for which the defendant was convicted, then the judge is to add the quantity of drugs from the dismissed count to the quantity in the convicted count to determine the base offense level. See United States Sentencing Commission, Trainer's Manual, Relevant Conduct Packet, Quiz 2, 4 (GPO, 1989).

${ }_{28}$ Guidelines Manual § $1 \mathrm{~B} 1.3(\mathrm{a})(2)$, quoted in note 25 , applies to activities used in calculating the base offense level, as well as adjustments to the base offense level. Thus, the question regarding burden of proof applies both to evidence determining the base offense level and evidence supporting an adjustment to the base offense level.

20 Id at $\S 6 \mathrm{~A} 1.1$. The judge uses this report as the basis for his determinations. If neither side disputes allegations in the presentence report, the court accepts them without any hearing. For a discussion of the role of the presentence report in sentencing, see United States v Palta, 880 F2d 636 (2d Cir 1989); Note, A Proposal to Enzure Accuracy in Presentence Investigation Reports, 91 Yale L J 1225 (1982). 
opportunity to present information to the court regarding that factor. ... [T] he court may consider relevant information ... provided that the information has sufficient indicia of reliability to support its probable accuracy..$^{30}$

The Commentary to this section explains that the court should resolve many of these factors in an informal fashion and need not always conduct a sentencing hearing. ${ }^{31}$ The Guidelines leave various procedural details open: "the sentencing court must determine the appropriate procedure in light of the nature of the dispute, its relevance to the sentencing determination, and applicable case law." 32 Because the Commission did not specify a burden of proof for sentencing determinations, this decision is also apparently left to the court's discretion.

A proposed version of the Guidelines would have required a judge to apply a preponderance of the evidence standard in resolving disputed sentencing factors, ${ }^{33}$ but the final version did not contain such a provision. In the Supplemental Report to the Guidelines, the Commission noted that the proper standard of proof was the type of sentencing factor that trial courts would have to resolve themselves. The Commission realized that the existing law "addressing dispute resolution . . . remains to be developed fully,"34 and thus implied that as case law developed under the Guidelines, courts would determine the requisite standard of proof..$^{35}$

so Guidelines Manual $\S 6 \mathrm{A1} .3$ (cited in note 2).

s1 Id, Commentary to $\$ 6$ A1.3.

32 Id.

3s United States Sentencing Commission, Preliminary Draft of Sentencing Guidelines for the United States Courts, 51 Fed Reg 35080, 35085 (1986). In adopting the preponderance standard, the Preliminary Draft tried to impose practices and "doctrines that were developed for a system of discretionary sentencing" on a new system which is "animated by considerations that are necessarily different from, and seen antithetical to the considerations that inhere in the new, determinate system." Harvey M. Silet and Susan W. Brenner, Commentary on the Preliminary Draft of the Sentencing Guidelines Issued by the United States Sentencing Commission in September, 1986, 77 J Crim L \& Criminol 1069, 1079 (1986).

34 United States Sentencing Commission, Supplementary Report of the Initial Sentencing Guidelines and Policy Statements, in Thomas W. Hutchinson and David Yellen, Federal Sentencing Law and Practice 200-02 (West, Supp 1989).

36 Some supplementary materials indicate that the Commission did contemplate a more definite standard of proof. For example, in testimony before the Senate Committee on the Judiciary, Sentencing Commissioner Stephen Breyer indicated that the proper standard for a judge to apply in resolving a disputed sentencing factor was preponderance of the evidence. Testimony of Sentencing Commissioner Stephen Breyer Before the Senate Committee on the Judiciary, reprinted in Kenneth R. Feinberg, Federal Sentencing Guidelines 830 (PLI, 1987). Additionally, a Federal Judicial Center committee explained that before the Guidelines, preponderance of the evidence was the appropriate standard for disputed fac- 
The Guidelines ultimately leave the burden of proof to a trial judge's discretion. In exercising this discretion, courts have generally adopted preponderance of the evidence as the burden of proof at sentencing, ${ }^{36}$ reasoning as follows: First, due process does not require a standard of proof higher than preponderance of the evidence. $^{37}$ Second, before the Guidelines, judges applied a preponderance standard for sentencing factors, ${ }^{38}$ and there is no reason to impose a higher burden of proof under the Guidelines. ${ }^{39}$ However, it is far from clear that this analysis comports with Supreme Court doctrine on the constitutionally required burden of proof in criminal proceedings or with the Court's general due process jurisprudence. Both of these issues deserve closer scrutiny; this Comment will first consider the Court's decisions on the burden of proof in criminal proceedings.

tors at a sentencing hearing, and that under the Guidelines, that standard should continue to suffice. The Committee did suggest, however, that with regard to "high impact issues," courts might have to apply a higher standard of proof. Judicial Conference Probation Committee, Federal Judicial Center In-Court-Educational Program on Guideline Sentencing Orientation, Recommended Procedures for Guideline Sentencing and Commentary, reprinted in Feinberg, Federal Sentencing Guidelines at 782. Unfortunately, the term "high impact issue" was not defined in the report and no subsequent report appears to explain the term. In any event, the final version of the Guidelines is silent on the issue of burden of proof.

ss See, for example, United States v Blanco, 888 F2d 907 (1st Cir 1989); United States v Guerra, 888 F2d 247 (2d Cir 1989); United States v McDowell, 888 F2d 285 (3d Cir 1989); United States v Harris, 882 F2d 902 (4th Cir 1989); United States v Taplette, 872 F2d 101 (5th Cir 1989); United States v Silverman, 889 F2d 1531 (6th Cir 1989); United States v White, 888 F2d 490 (7th Cir 1990); United States v Ehret, 885 F2d 441 (8th Cir 1989); United States v Wilson, 900 F2d 1350 (9th Cir 1990); United States v Fredericks, 887 F2d 494 (10th Cir 1990); United States v Scroggins, 880 F2d 1204 (11th Cir 1989); United States $v$ Burke, 888 F2d 862 (DC Cir 1989). But see United States v Davis, 715 F Supp 1473 (C D Cal 1989), disapproved of by United States $v$ Rafferty, 911 F2d 227 (9th Cir 1990). For a discussion of the general use and effect of the preponderance standard at sentencing, see Robert E. Hanlon, The Second Circuit Review-1986-1987 Term: Criminal Procedure: Hard Time Lightly Given: The Standard of Persuasion at Sentencing: United States v. Lee a/k/a "Monkey", 54 Brooklyn L Rev 465 (1988).

${ }^{37}$ See, for example, Williams, 880 F2d 804; Koonce, 884 F2d 349.

3s See, for example, United States v Lee, 818 F2d 1052 (2d Cir 1987).

38 See, for example, McDowell, 888 F2d 285; Guerra, 888 F2d 247. One court has disagreed, holding that the Guidelines are unconstitutional because of the general lack of procedural safeguards at sentencing. In dictum, this court also stated that even if preponderance were the appropriate standard, the Guidelines would remain unconstitutional. Davis, 715 F Supp 1473. Subsequent Ninth Circuit decisions, however, question the authority of Davis. See, for example, Wilson, 900 F2d 1350. 


\section{The Current Framework: Constitutionality of the Preponderance Standard Unclear}

Supreme Court interpretations indicate that the Due Process Clause of the Constitution mandates a minimum standard of proof in criminal proceedings, and the Court's decisions establish a framework for determining whether the Due Process Clause requires a standard higher than preponderance of the evidence under the Guidelines. These cases call into question the reasoning employed by lower courts addressing the constitutionality of the preponderance standard under the Guidelines, but they do not conclusively determine the constitutionally required burden of proof at sentencing under the Guidelines. ${ }^{40}$

\section{A. Burden of Proof Requirements in Criminal Proceedings}

In In re Winship, ${ }^{41}$ the Supreme Court held that due process requires that every factor necessary to convict a defendant of a crime be proven beyond a reasonable doubt. ${ }^{22}$ In reaching this decision, the Court relied on the historical tradition of American law and the need for confidence in the criminal law system. ${ }^{43}$ In a concurring opinion, Justice Harlan explained that under the American system of criminal justice it is better to allow a guilty man to go free than to convict an innocent man. ${ }^{44}$

Elaborating on this requirement in Mullaney $v$ Wilbur, the Court struck down a Maine murder statute that presumed the presence of malice aforethought unless the defendant proved he acted in the heat of passion. ${ }^{4}$ The Court held this scheme unconstitutional, stating that the prosecution must "prove beyond a reasonable doubt the absence of the heat of passion on sudden provocation," ${ }^{46}$ because malice aforethought was an element of the crime

\footnotetext{
10 The Supreme Court recently upheld the Guidelines against constitutional challenges based upon separation of powers and unlawful delegation, Mistretta, 489 US 361, but the Court has yet to address the constitutionality of a preponderance standard at sentencing. Another possible due process attack on the Guidelines is that defendants do not receive an individually determined sentence. See Bradford C. Mank, Do the United States Sentencing Guidelines Deprive Defendants of Due Process?, 37 Drake L Rev 377 (1987-88).

41 397 US 358 (1970).

12 Id at 364 .

13 Id.

14 Id at 372 .

45421 US 684 (1975). If defendant could prove heat of passion, the court would reduce the charge to manslaughter.

16 Id at 704.
} 
of murder in Maine. Yet a year later, in Patterson $v$ New York, ${ }^{\mathbf{4 7}}$ the Court upheld a New York murder statute that placed on the defendant the burden of proving that his actions were attributable to extreme emotional disturbance. ${ }^{48}$ The Court held that this allocation of burden of proof did not violate the Due Process Clause because it did not require the defendant to prove an actual element of the crime. ${ }^{49}$ The Patterson Court, however, did prescribe some limits on a state's ability to define a crime. A legislature cannot declare someone " "presumptively guilty of a crime" " nor can a legislature "validly command that the finding of an indictment, or mere proof of the identity of the accused, [creates] a presumption of the existence of all the facts essential to guilt." "\$o

Against this legal backdrop the Court decided McMillan $v$ Pennsylvania. ${ }^{\text {"I }}$ McMillan was charged and convicted of aggravated assault. Pennsylvania law imposed a five-year minimum sentence on defendants who visibly possessed a firearm during the commission of certain felonies. ${ }^{62}$ The trial court determined at sentencing, by preponderance of the evidence, whether a visible firearm was present. ${ }^{53}$ Thus, a defendant receives this mandatory sentence based on a fact not an element of the crime, and not proven beyond a reasonable doubt at trial. The Supreme Court upheld the constitutionality of the Pennsylvania sentencing scheme by a 5-4 vote.

In his majority opinion, Justice Rehnquist first reiterated Winship: "the Due Process Clause protects the accused against conviction except upon proof beyond a reasonable doubt of every

4742 US 197 (1977).

48 For a discussion of how to resolve Mullaney and Patterson, see Ferdinand M. Dutile, The Burden of Proof in Criminal Cases: A Comment on the Mullaney-Patterson Doctrine, 55 Notre Dame Lawyer 380 (1980). For the view that Mullaney extended due process protection too far, and Patterson was a correction of the Court's error, see Ronald J. Allen, The Restoration of In re Winship: A Comment on Burdens of Persuasion in Criminal Cases After Patterson v. New York, 76 Mich L Rev 30 (1977). For a discussion of the proposition that Patterson incorrectly did away with the constitutionally mandated protection of the Due Process Clause, see Marina Angel, Substantive Due Process and the Criminal Law, 9 Loyola U Chi L J 61, 93-111 (1977). See also Mark W. McLane, The Burden of Proof in Criminal Cases: Mullaney and Patterson Compared, 15 Crim L Bull 346 (1979).

60 The Court reasoned that the New York statute was constitutional, because if the state has the greater power to punish someone for killing another, then it also has the lesser power not to recognize emotional distress as a mitigating circumstance at all. Thus, requiring the defendant to bear the burden of proving emotional distress is constitutionally permissible. Patterson, 432 US at 209.

so Id at 210 (citations omitted).

s1 477 US 79 (1986).

${ }^{52} 42 \mathrm{~Pa}$ Cons Stat Ann $\$ 9712$ (Purdon 1989).

ss Id. 
fact necessary to constitute the crime with which he is charged." 54 Distinguishing Winship, the Court rejected the argument that possessing a gun was an element of the crime, reasoning that "visible possession of a firearm is [instead] . . . a sentencing factor that comes into play only after the defendant has been found guilty of one of those crimes beyond a reasonable doubt." Rehnquist noted that judges traditionally have wide discretion in sentencing convicted defendants, and thus held that a state legislature did not offend the Due Process Clause by providing concrete guidance to a trial court on how to exercise its discretion. ${ }^{56}$ The Court upheld the Pennsylvania statute. ${ }^{57}$

Although the majority rejected the argument that a higher standard of proof was necessary under the Pennsylvania scheme, the Court did indicate that other situations might require a higher standard of proof. Justice Rehnquist stated:

[I]n certain limited circumstances Winship's reasonabledoubt requirement applies to facts not formally identified as elements of the offense charged. ... While we have never attempted to define precisely the constitutional limits noted in Patterson, i.e., the extent to which due process forbids the reallocation or reduction of burdens of proof in criminal cases, and do not do so today, we are persuaded by several factors that Pennsylvania's Mandatory Minimum Sentencing Act does not exceed those limits. ${ }^{.8}$

While not expressly setting forth a test to determine when the Due Process Clause would require a higher standard of proof, ${ }^{59}$ the

34 McMillan, 477 US at 84, quoting Winship, 397 US at 364.

${ }^{\text {ss }}$ Id at 85-86. In rejecting the argument that possessing a gun was an element of the crime, the Court had to reconcile its decisions in Mullaney and Patterson. The majority emphasized the formal differences between the statutory language in the two cases, id at 8486, and stressed that the principal teaching of Patterson was that the "state need not "prove beyond a reasonable doubt every fact, the existence or nonexistence of which it is willing to recognize as an exculpatory or mitigating circumstance affecting the degree of culpability or the severity of the punishment." "Id at 84, quoting Patterson, 432 US at 207.

BE Id at 92.

${ }^{67}$ In dissent, Justice Stevens rejected the approach adopted by the majority. Instead, Stevens made a distinction with which all four of the dissenters agreed: "if a State provides that a specific component of a prohibited transaction shall give rise both to a special stigma and to a special punishment, that component must be treated as a 'fact necessary to constitute the crime' within the meaning of our holding in In re Winship." McMillan, 477 US at 103 (Stevens dissenting).

se Id at 86.

35 It is also unclear whether the court intended that the presence of these factors would merely suggest a standard higher than preponderance or would in fact require proof beyond a reasonable doubt. The Court's rejection of the clear and convincing standard, 477 US at 92 
Court did note the absence of several factors, which, if present, might have mandated a higher standard. ${ }^{30}$

First, the Court noted that the mandatory five-year sentence was within the statutory maximum for aggravated assault. ${ }^{61}$ The Court reasoned that the five-year minimum "operate[d] solely to limit the sentencing court's discretion in selecting a penalty within the range already available to it without the special finding of visible possession of a firearm." ${ }^{62}$ The Court explained that if visible possession exposed a defendant to punishment outside this range, then the defendant's claim-that due process required a higher standard of proof-would have more merit. ${ }^{63}$

Second, the Court emphasized that "the statute gives no impression of having been tailored to permit the visible possession finding to be a tail that wags the dog of the substantive offense." While the Court did not indicate exactly what would constitute "a tail wagging the dog," it implied that if a statute met this criteria, due process might require a higher standard of proof.

Third, the Court noted that Pennsylvania was not trying to evade Winship by not defining the presence of a gun as an element of the crime. ${ }^{65}$ According to the Court, the Pennsylvania legislature had merely "[taken] one factor that has always been considered by sentencing courts to bear on punishment-the instrumentality used in committing a violent felony-and dictated the precise weight to be given that factor if the instrumentality is a firearm."'66 The Court left open the possibility that if a sentencing practice was an attempt to evade the Winship requirements, then it may be subject to a higher burden of proof.

Current Supreme Court doctrine indicates that the Due Process Clause requires a standard higher than preponderance only in certain circumstances. If a particular factor is an element of the crime, proof beyond a reasonable doubt must be satisfied. Alterna-

\footnotetext{
n 8, suggests that the Court may have contemplated only a burden of proof higher than preponderance. See Section III.B.

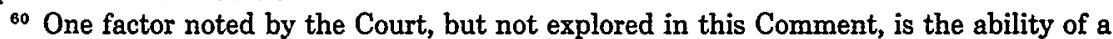
legislature to define a crime to consist of so few elements that a defendant is presumptively guilty unless he proves otherwise. McMillan, 477 US at 86-87, citing Patterson, 432 US at 210.

1 The statutory maximum for aggravated assault was 10 years. $18 \mathrm{~Pa}$ Cons Stat Ann $\S \S 1103(2), 2702(a)$ (1) (Purdon 1982).

${ }^{22}$ McMillan, 477 US at 88.

as Id at $87-88$.

o4 Id.

${ }^{65}$ Id at 89-90.

${ }^{68}$ Id at 89 .
} 
tively, if one or more of the three McMillan exceptions applies, a standard higher than preponderance may be constitutionally required.

B. Use of a Preponderance Standard Under the Guidelines May Be Inconsistent with McMillan

Determining the base offense level and calculating adjustments to it raise issues that the McMillan majority indicated could require a burden of proof higher than preponderance. Both findings require the judge to make factual determinations that subject the defendant to greater punishment, that function as "tails that wag the dog of the substantive offense," and that evade the requirements of Winship.

\section{Greater punishment.}

In order to understand how factual findings under the Guidelines may subject a defendant to greater punishment, it is useful to compare the federal regime to Pennsylvania's system of sentencing guidelines for trial judges. ${ }^{67}$ Like the Federal Guidelines, the Pennsylvania Guidelines consider both the particular crime of the defendant and the defendant's criminal history, in order to determine the applicable minimum range (analogous to the actual sentence range obtained from applying the matrices of the Federal Guidelines). ${ }^{68}$ Unlike the Federal Guidelines, however, the Pennsylvania Guidelines only prescribe minimum sentence ranges. ${ }^{69}$

The Pennsylvania trial judge may depart from this minimum range to impose a higher sentence if he has reasons to justify a departure. Pennsylvania courts interpret the trial judge's discretion to depart from the state's minimum guideline range much more expansively than federal courts interpret the trial judge's discretion to depart from the Federal Guidelines. In Pennsylvania, the judge has discretion to depart from the state guidelines, as long as the sentence he imposes is within the theoretical statutory maximum (the maximum amount of time a defendant could spend in prison if he were found guilty of a certain crime), he states his reasons on the record, and the sentence reflects three general concerns: the need to protect the public, the gravity of the offense (including the impact of the crime on the victim), and the rehabilita-

\footnotetext{
${ }^{67}$ See $204 \mathrm{~Pa}$ Code $\S 303$, in $42 \mathrm{~Pa}$ Cons Stat Ann $\$ 9721$ (Purdon 1989).

os Id.

so Id.
} 
tive needs of the defendant. ${ }^{70}$ Thus, the Pennsylvania trial judge has the discretionary power to impose the theoretical statutory maximum sentence for a given crime on a particular defendant. In McMillan, the court properly used the theoretical statutory maximum as a baseline against which to determine whether a finding of visible possession of a firearm led to additional punishment, because the trial judge had discretion to sentence a particular defendant to this maximum.

The McMillan reasoning technically applies to the Guidelines, because all sentences imposed under the Guidelines are subject to a theoretical statutory maximum for the particular crime of which the defendant has been convicted. Unlike the Pennsylvania scheme, however, the theoretical statutory maximum in federal sentencing is not a realistic option for federal trial judges; ${ }^{71}$ the standard a federal judge must satisfy before he can depart from the Federal Guidelines' range is much higher than that of the Pennsylvania trial judge. ${ }^{72}$ Under the Federal Guidelines, the theoretical statutory maximum is not a sensible baseline for due process analysis.

The Guidelines require a judge to impose a sentence within a very small range, ${ }^{73}$ which is set by the judge's own findings on the quantity of contraband and the defendant's criminal history category. Although the Guidelines do leave some room for departing from this range, courts have interpreted this discretionary power very narrowly. ${ }^{74}$ Thus, a federal judge's discretion under the

\footnotetext{
${ }^{70}$ Commissioner v Smith, $369 \mathrm{~Pa}$ Super 1, 534 A2d 836 (1987); Commissioner v Cruz Ortega, $372 \mathrm{~Pa}$ Super 389, 394, 539 A2d 849 (1988).

${ }_{71}$ If the federal judge can demonstrate that factors exist justifying a departure, he can impose a sentence outside the Guideline range, but as previously suggested, this is a very high standard to meet. In White, the Seventh Circuit noted that a sentence is imposed within the Guideline range in $82 \%$ of all cases. 888 F2d at 498, citing United States Sentencing Commission, 1988 Annual Report 37-38 (GPO, 1989). The latest annual report confirms this figure. United States Sentencing Commission, 1989 Annual Report 59 (GPO, 1990).

${ }_{72}$ Although it is true that sentences under the Federal Guidelines are much shorter on average than sentences that trial judges imposed in federal courts before the Guidelines, this comparison is misleading. When a defendant receives a sentence under the Federal Guidelines the defendant will serve the full length of the sentence without any possibility that parole will shorten the sentence. Before the Federal Guidelines, the parole option made the sentence actually served by a defendant much shorter than that imposed by the court. Guidelines Manual, ch 1 at 3 (cited in note 2).

${ }^{73}$ See notes 14-15 and accompanying text.

74 See United States v Aguilar-Pena, 887 F2d 347, 349-50 (1st Cir 1989); United States $v$ Coe, 891 F2d 405, 413 n 9 (2d Cir 1989); United States v Rivalta, 892 F2d 223 (2d Cir 1989); United States v McDowell, 902 F2d 451 (6th Cir 1990); United States v Schmude, 901 F2d 555 (7th Cir 1990). Compare Taplette, 872 F2d at 106; Ryan, 866 F2d at 609-10.
} 
Guidelines stands in stark contrast to that allowed a state judge under the Pennsylvania sentencing scheme.

Unlike a Pennsylvania judge's finding of the visible possession of a firearm, a finding of a certain quantity of contraband does expose a federal defendant to greater punishment. With drug crimes, if the trial judge finds that the amount of drugs involved in the crime is greater than that proven at trial, the defendant's base offense level, and therefore his sentence, increases. In contrast to the Pennsylvania judge's finding of a visible firearm in McMillan, these decisions do not merely establish the minimum sentence for a convicted defendant. Rather, these findings in fact determine the defendant's sentence, because the trial judge can only deviate from the Guidelines' range in narrow circumstances. These findings, then, expose a defendant to greater punishment. Unlike the Pennsylvania judge's finding in McMillan, a federal judge's findings do more than limit the range already available to the court. The federal judge's findings at sentencing set the "range" available to the judge.

Thus, under the Federal Guidelines, the relevant baseline against which to judge whether certain factual determinations merit extra punishment is the actual sentence that a defendant with a particular base offense level and criminal history will receive under the Guidelines. ${ }^{75}$ If one uses this baseline, a finding of extra drugs, which increases the base offense level, does subject a defendant to a greater level of punishment. Similarly, if a defendant's base offense level is adjusted upward due to aggravating circumstances, then the facts underlying the upward adjustment also lead to a greater punishment. Because these factual findings have the potential to increase sentences, they should arguably be subject to a standard of proof greater than preponderance under McMillan.

2. Tail wagging the dog.

Another factor the McMillan Court noted might warrant a higher burden of proof is whether the factual determination was

${ }^{75}$ This is the appropriate baseline, because it is really the only sentencing option available to the trial judge. To measure a defendant's sentence against a backdrop which in practice is not an available option seems questionable at best. There are two important qualifications to this rule. First, for any given offense level and criminal history category, the judge has discretion within a sentencing range. However, the range is so slight that this aspect of judicial discretion is all but meaningless. See note 14. Second, as discussed at note 15, the Guidelines do allow for departure in limited circumstances. In practice such departure rarely occurs. See note 71 . This is significantly different from the Pennsylvania sentencing scheme at issue in McMillan. 
really a "tail that wagged the dog of the substantive offense." The McMillan Court probably contemplated a situation in which the factual determinations made at sentencing so control the punishment decisions that they, rather than the elements of the substantive offense, become the prime criteria in fixing punishment. Determining the base offense level and adjustments seems to exemplify this phenomenon because of the effect of these determinations on punishment.

In order to calculate the base offense level, a court needs to know the amount of drugs or money involved in the crime. Accordingly, the quantity of contraband determines the sentence. The determination of adjustments also contributes to the fixing of punishment. Each adjustment will change the base offense level and consequently the sentence imposed.

Under the Pennsylvania Guidelines, a trial judge could sentence a defendant not possessing a firearm to an equal or longer term than a defendant possessing a firearm. This potential overlap suggests that the determination of the gun's presence is not a crucial element to sentencing in Pennsylvania. The elements of the substantive offense set the maximum sentence, and a trial judge retains the discretion to set the sentence based on a number of factors. In this way, the "dog" (the substantive elements) wags the "tail" (the factors allowing adjustment).

However, the same is not true under the Federal Guidelines. Consider a defendant, with no prior criminal history nor circumstances warranting an adjustment to the base offense level, charged with illegal possession of base cocaine. If the court convicts the defendant of possessing one gram of cocaine, the base offense level will be 18. This translates into a sentence of $27-33$ months. ${ }^{76}$ If, on the other hand, a judge finds at sentencing that the amount of drugs actually involved in the transaction was 35 grams, the base offense level will be 30 , translating into a sentence of 97-121 months. ${ }^{77}$ The sentence imposed for one gram of base cocaine does not overlap with that imposed for 35 grams. $^{78}$ This same argument applies to adjustments to the base offense level. ${ }^{79}$

${ }^{76}$ Guidelines Manual § 2D1.1(c)(13) (cited in note 2).

77 Id at § $2 \mathrm{D} 1.1(\mathrm{c})(7)$.

${ }^{78}$ Id. In fact, the sentences do not overlap even when the comparison is between one gram of cocaine and three grams of cocaine, which under the same assumptions, will be 41 51 months. § 2D1.1(c)(11).

${ }^{79}$ For example, if the defendant in the above example was found to have had a firearm present during the transaction, his base offense level would have been 20 for 1 gram of base 
Thus, under the Guidelines' sentencing system, the elements of the substantive offense may be less important than other factors considered by the judge. The sentence of a defendant convicted of cocaine possession is determined for the most part by the quantity of cocaine, a factual inquiry by the judge at sentencing. The absence of any common range between the sentences in the above example suggests that the quantity of cocaine is in fact a "tail" that "wags the dog" of the substantive offense of cocaine possession.

\section{Evading Winship.}

The Guidelines' scheme also evades the requirements of Winship. Consider a scenario in which the government charges a defendant with two related counts of drug possession. ${ }^{80}$ The defendant pleads guilty to the first count in exchange for the government dropping the second count. If the judge determines that the count dismissed was part of the same course of conduct as the count under which the court convicted the defendant, the defendant will receive the same punishment as if found guilty of both counts, because under $\S 3 \mathrm{D} 1.2$ the court would aggregate the quantities of the two original counts. ${ }^{81}$ The government thus evades the burden of establishing beyond a reasonable doubt at trial that the defendant committed the second count; yet, under the lesser burden of preponderance, the government achieves the same result by establishing the presence of the drugs at sentencing. ${ }^{82}$ This evades the Winship requirement that every element of the crime be proven beyond a reasonable doubt.

The same argument applies to adjustments to the base offense level. Consider a defendant charged with a drug offense and a gun offense. At trial, the jury acquits him of the gun offense but con-

cocaine, translating into a sentence of 33-41 months. Without a firearm, his sentence would be 27-33 months. Similarly, for 35 grams of base cocaine, defendant will receive a sentence of 97-121 months if he does not have a gun, and a sentence of 121-151 months (base offense level of 32) if he does have a gun. Id at $\S 2 D 1.1(b)(1)$.

${ }^{80}$ This precise situation is an example in the Trainer's Manual. See note 27.

s2 See text at notes $23-27$ for an explanation of § 3D1.2.

*2 This argument was advanced by the defendant in United States $v$ Fernandez, 877 F2d 1138 (2d Cir 1989). The defendant, as part of a plea agreement, decided to plead guilty to a lesser charge involving a smaller amount of cocaine. At the time of the plea, the judge told the defendant that he was still subject to the theoretical statutory maximum for the crime initially charged. At sentencing, the judge included the full amount of drugs specified in the initial charge. The Second Circuit upheld the sentence because the defendant in fact received a sentence less than the theoretical statutory maximum. See also Silet and Brenner, $77 \mathrm{~J}$ Crim L \& Criminol 1069 (cited in note 33). 
victs him of the drug offense. At sentencing, if the judge believes by preponderance that the gun was involved in the transaction, he can adjust the base offense level upward to reflect the presence of the gun. ${ }^{83}$ This too evades the Winship requirement of proof beyond a reasonable doubt.

$$
* * * *
$$

The Guidelines' method of calculating both the base offense level and adjustments satisfies the factors enumerated in McMillan, each of which may warrant a burden of proof higher than preponderance. The Court in that case explicitly refused to adopt a bright-line test, however, only mentioning factors that might produce a different result. Moreover, the McMillan opinion does not make clear whether the presence of these factors mandates proof beyond a reasonable doubt or merely a standard higher than preponderance. ${ }^{84}$ One must therefore embark upon a more general due process analysis in order to ascertain the correct evidentiary standard.

\section{Supreme Court Doctrine Supports Clear and Convincing Evidence as the Proper Standard at Sentencing}

McMillan fails to provide a clear answer to the burden of proof issue because the Pennsylvania statute is an inadequate analogy for the Guidelines. This inadequacy stems from the fundamental differences between the Guidelines' sentencing regime and the Pennsylvania regime at issue in McMillan. Previous Supreme Court decisions on the burden of proof in criminal cases involved sentencing schemes in which the trial judge enjoyed a large amount of discretion; such discretion does not exist under the Guidelines. ${ }^{85}$ With a discretionary approach, a judge not only

${ }^{83}$ The Fifth Circuit upheld this result in United States v Juarez-Ortega, 866 F2d 747 (5th Cir 1989). See Guidelines Manual \& 2D1.1(b)(1) (cited in note 2).

${ }^{84}$ The evasion of Winship factor, while relevant, is not dispositive of this issue. Because Winship only prescribes proof beyond a reasonable doubt, it is difficult to equate evasion of Winship with anything less than this standard. However, the Court seemed to distinguish an attempt to evade Winship with an outright violation of Winship. The Court has applied quite formal distinctions in this area in the past (Patterson/Mullaney), and it may do so again in this context, holding that while this factor evades Winship, it does not violate Winship. In these situations, factual determinations may require reasonable doubt or an intermediate standard of proof between preponderance and beyond a reasonable doubt.

${ }^{85}$ Drawing an even starker contrast to the federal judge's lack of discretion under the Guidelines (see text at notes 75-77), under Pennsylvania law both the judge and prosecutor have discretion to decide whether to invoke the provision mandating a five-year minimum sentence for the use of a visible firearm. See Commonwealth $v$ Pittman, $515 \mathrm{~Pa} 272,528$ A2d 138 (1987). 
weighs a wider array of considerations, he also factors into the sentencing calculus his relative degree of certainty relating to each consideration..$^{86}$ Under the Guidelines, however, judges must assign fixed weights to factual determinations at sentencing, regardless of their relative degree of certainty (as long as the preponderance standard is met); the presence of discretion makes the McMillan decision meaningfully different. Because of this inadequacy, one must apply a more general due process analysis, which suggests that in implementing the Guidelines trial judges should adopt clear and convincing evidence as the standard of proof at sentencing.

\section{A. Due Process Framework}

Sentencing following conviction presents unique due process concerns, which can be analyzed using the framework enunciated by the Supreme Court in Mathews $v$ Eldridge. ${ }^{87}$ The analysis requires balancing three factors: the private interest, the risk of erroneous deprivation or the value of additional safeguards, and the governmental interest. ${ }^{88}$ The private interest implicated at sentencing under the Guidelines is the serving of an erroneously long sentence. The risk of erroneous deprivation and the value of additional safeguards relate to the question of whether the defendant will suffer an erroneously long sentence if a lower burden of proof is applied. The governmental interest is the economic and deterrence costs of a higher burden of proof. The ultimate result under Mathews depends on how one reconciles these three considerations. Supreme Court jurisprudence on the role of the burden of proof indicates that clear and convincing evidence is the proper

88 This was precisely the argument of the district court in Davis, 715 F Supp at 1479 , and is similar to Silet and Brenner's argument, $77 \mathrm{~J}$ Crim L \& Criminol at 1079 (cited in note 33 ).

87 424 US 319,335 (1976).

68 While Mathews does not clearly apply to criminal sentencing cases-the case itself concerned social security benefits-circuit courts have applied these three factors in the criminal sentencing context. See, for example, United States $v$ Barnerd, 887 F2d 841, 843 (8th Cir 1989); United States v Lee, 818 F2d 1052, 1056 (2d Cir 1987); United States $v$ Pugliese, 805 F2d 1117, 1122-23 (2d Cir 1986); United States $v$ Davis, 710 F2d 104, 107 (3d Cir 1983). Additionally, while the Supreme Court has not explicitly adopted the Mathews test in this setting, no language in Mathews appears to limit the test to the administrative hearing context. Indeed, the factors enunciated in this balancing test are the precise issues that must arise in any due process analysis. One commentator has noted the similarity between the Mathews opinion and the reasoning of the Court in Patterson. Comment, Fifth Amendment-Due Process Rights at Sentencing, 77 J Crim L \& Criminol 646, 662-63 (1986). 
constitutional standard for resolving sentencing factors under the Guidelines.

The Supreme Court's opinion in Addington $v$ Texas ${ }^{8 \theta}$ clearly states the two purposes of the burden of proof. First, it serves to " instruct the factfinder concerning the degree of confidence our society thinks he should have in the correctness of factual conclusions for a particular type of adjudication." "In the context of the Guidelines, this concern translates into how much certainty the criminal justice system ought to demand in determining the facts relevant to the length of a sentence. Second, the standard chosen "serves to allocate the risk of error between the litigants and to indicate the relative importance attached to the ultimate decision."91

There are three basic evidentiary standards available: preponderance of the evidence, clear and convincing evidence, and evidence beyond a reasonable doubt. These three standards constitute a continuum, with the least restrictive standard-preponderanceapplied to civil cases because "society has a minimal concern with the outcome of such private suits," dard-beyond a reasonable doubt-applied to criminal determinations of guilt because "the interests of the defendant are of such magnitude that historically and without any explicitly constitutional requirement they have been protected by standards of proof designed to exclude as nearly as possible the likelihood of an erroneous judgment." Clear and convincing evidence is an intermediate standard appropriate when "the interest[s] at stake ... are deemed to be more substantial than mere loss of money . . . ."94 In Addington, the Court held that the Due Process Clause required the use of a clear and convincing standard in order to civilly confine a person "involuntarily for an indefinite period to a state mental hospital," reasoning that the loss of liberty of the person was an interest that was more substantial than the loss of money.95

${ }^{89} 441$ US 418 (1978).

so Id at 423 (citations omitted).

si Id.

92 Id.

is Id at 423-24.

* Id at 424 .

${ }^{28}$ Id at 420 . For other instances where the clear and convincing standard is applied, see California o Mitchell Bros.' Santa Ana Theater, 454 US 90, 93 (1981) (per curiam). The areas include libel, deportation, and denaturalization. 


\section{B. Adoption of the Clear and Convincing Evidence Standard}

The burden of proof at sentencing for a criminal offense does not fit neatly into this continuum. Traditional Court doctrine requires the beyond a reasonable doubt standard for criminal proceedings, but such Court decisions only treat determinations of guilt. ${ }^{98}$ At sentencing, the guilt of the defendant is not at issue. But while the beyond a reasonable doubt standard is not clearly applicable, neither are the preponderance or clear and convincing standards, because courts have rarely applied either of these standards outside the civil law context. ${ }^{97}$ Balancing the relevant factors identified in the Mathews analysis, however, dictates that clear and convincing evidence is the appropriate standard.

The private interest of the defendant supports a high standard of proof. A lower standard of proof may cause an error in a factual determination needed to calculate the base offense level or an adjustment to the base offense level and thereby lead to a longer sentence. ${ }^{98}$ If due process demands that some guilty people may go free because of the risk of convicting an innocent person, it may also demand that some defendants receive erroneously short sentences to counteract the risk of other defendants receiving erroneously long sentences. The underlying interest that the Winship Court found so important was the protection of liberty. The defendant's interest in not receiving an erroneously long sentence is similar to his interest in not being falsely convicted; both involve the wrongful taking of liberty. Because the factual determinations in question at the sentencing hearing determine the length and the range of a sentence, Winship may require as a subsidiary principle

\footnotetext{
94 There is one important exception. In United States v Salerno, 481 US 739 (1987), the Court addressed the constitutionality of the Bail Reform Act, Pub L No 98-473, 98 Stat 1976, codified at 18 USC $\$ \$ 3141-50$ (1988). Under this act, an arrestee may be detained if, after a hearing,

the judicial officer finds that no conditions of pretrial release can reasonably assure the safety of other persons and the community, [and] he must state his findings of fact in writing, \& 3142(i), and support his conclusion with clear and convincing evidence, $\S 3142(f)$.

481 US at 742 (emphasis added). While the Court sustained the constitutionality of the Bail Reform Act with clear and convincing evidence as the burden of proof, the Court did not analyze clear and convincing evidence itself as a due process issue.

97 The clear exception is McMillan. However, the Court in McMillan did not hold that the Due Process Clause required preponderance, but rather that preponderance satisfied due process concerns. See 477 US at 91.

os Throughout this section no distinction is drawn between the base offense level and adjustments to the base offense level. The analysis for base offense level and adjustments should be the same because an error in either will increase or decrease the sentence. See text at notes 13-20 for a more complete discussion.
} 
that the social benefit of not imposing an erroneously long sentence is worth the social cost of imposing an erroneously short sentence. The Addington Court also understood that the private liberty interest implicated by a civil commitment proceeding is protected by the Due Process Clause, and requires proof by clear and convincing evidence.9

In addition, as Justice Rehnquist points out in McMillan, the concern about erroneous deprivation at sentencing is not as great as it is at trial, because the defendant has already been found guilty. ${ }^{100}$ The level of risk one is willing to tolerate is higher, because the question is not about whether the accused will go to prison, but rather how long he will stay in prison. Even though it is possible for defendants to receive distinct sentences depending on how one resolves issues in calculating the base offense level, ${ }^{101}$ and even though it is true that these determinations are like elements of the crime, it is nevertheless true that the court has convicted the defendant of certain culpable activity. The determinations made at sentencing either go to the base offense level or to adjustments to the base offense level. Because these determinations relate to aspects of the defendant's conduct (which has already been proven culpable), the risk of error in calculating the base offense level and adjustments is more tolerable than the risk of error in determining guilt itself. The Addington Court reasoned similarly in holding that it was permissible to allow greater error in civilly confining a person than convicting a person of a criminal offense. ${ }^{102}$ Thus, this factor suggests that a standard lower than beyond a reasonable doubt may be sufficient.

Finally, one must evaluate the cost to the prosecution of a higher burden of proof. At first glance, this factor seems to support a lower standard. Potential costs of a higher burden of proof include expending extra prosecutorial resources, added judicial workload, and erroneously short sentences. And if the trial judge is required to resolve many factors to a higher degree of certainty, the sentencing hearing might overwhelm the trial.

These costs may be minimal under the Guidelines, however, because the calculation of the base offense level for drug and money crimes depends primarily on the quantity of contraband involved in the crime. Moreover, there are only a limited number of

\footnotetext{
99 Addington, 441 US at $425-27$.

${ }^{100}$ McMillan, 477 US at 83-84.

${ }^{101}$ See Section II.B.2.

${ }^{102}$ Addington, 441 US at 429.
} 
specific factors that the court must consider in calculating any adjustment to the base offense level. These adjustments are each discrete questions of fact, such as whether a gun was present, ${ }^{103}$ whether drugs were present, ${ }^{104}$ or whether the victim was a law enforcement officer. ${ }^{105}$ Because of the small number of discrete factual questions that the court must answer to calculate the base offense level and any adjustments, the costs of answering these questions will not be overly burdensome to the government. ${ }^{106}$ Furthermore, because the number of factual determinations that the judge must make at sentencing is quite limited, it is unlikely that the sentencing hearing would overwhelm the trial. ${ }^{107}$

In the end, it seems that clear and convincing evidence is the most appropriate standard to apply in the Guidelines' context, just as it was in Addington. In Addington, the Court had to wrestle with the loss of liberty from civil confinement. The Court, in rejecting a preponderance standard, understood the importance of this liberty interest and how it differed from a mere monetary interest. The Court reasoned that "[o]ne who is suffering from a debilitating mental illness and in need of treatment is neither wholly at liberty nor free of stigma." 108 The Court also understood, however, that the interest involved did not implicate issues of guilt or innocence. The Court thus rejected the beyond a reasonable doubt standard, reserving that standard for determinations of guilt in a criminal trial. ${ }^{108}$ The Court adopted a clear and convincing

${ }^{103}$ Guidelines Manual § 2D1.1(b)(1) (cited in note 2).

${ }^{104}$ Id at $\S 2 \mathrm{~B} 1.1(\mathrm{~b})(2)$.

100 Id at § 3A1.2.

108 With respect to the base offense level, see id at $\S 2$ B1.1 (larceny, embezzlement, and other forms of theft) and § 2D1.1 (unlawful manufacturing, importing, exporting, or trafficking). The types of factors which can adjust a base offense level applicable to all crimes include victim-related adjustments (see § 3A1.1-vulnerable victim; § 3A1.2-official victim; § 3A1.3-restraint of victim), role in the offense adjustments (see § 3B1.1-aggravating role; § 3B1.2-mitigating role; § 3B1.3-abuse of position of trust or use of special skill), and obstruction adjustments (see $\S 3 \mathrm{C} .1$-willfully obstructing or impeding proceedings). There are a few additional factors for each specific offense. For example, the specific offense characteristics for larceny and embezzlement are whether a firearm or drugs were present, whether the theft was from another person, whether US mail was taken, whether it involved more than minimal planning, or whether the crime involved organized criminal activity. See § 2B1.1. For drug crimes, the only specific offense characteristic is whether the defendant possessed a firearm during the offense. See $\S 2 D 1.1(b)(1)$. For money crimes, the Guidelines are written to make the amount of money involved in the offense a specific offense characteristic. See $\S 2 B 1.1$.

${ }^{102}$ See notes 8-12 and accompanying text.

${ }^{108}$ Addington, $441 \mathrm{US}$ at 429.

109 Specifically, the Court understood a civil commitment proceeding to be different, because it was not punitive in nature. The Court also noted that it may be impossible to 
standard because this "middle level of burden of proof [] strikes a fair balance between the rights of the individual and the legitimate concerns of the state."110

Similarly, under the Guidelines the defendant's guilt or innocence is not at issue, and thus beyond a reasonable doubt seems inappropriate. The system is willing to tolerate a higher degree of error in this context. Yet, it is equally true that the interest involved (avoiding an erroneously long sentence) is quite important to individual liberty ${ }^{111}$ and should be valued as a derivative rule of Winship. Just as preponderance was not sufficient to civilly confine a person, it is not sufficient to deprive a defendant of liberty at sentencing.

A clear and convincing standard is sensitive to these competing concerns in the Guidelines' context. As the constitutional analysis above makes clear, at sentencing the judge must resolve factual issues that expose the defendant to greater punishment, which essentially become elements of the crime, and which may in effect evade Winship. ${ }^{112}$ This analysis is relevant even if the preponderance standard does satisfy due process, because the Guidelines delegate the burden of proof decision to the discretion of the trial judge. In excercising this discretion, judges should take the considerations discussed in this Comment into account. The clear and convincing evidence standard is the appropriate burden of proof for resolving these factual issues because it effectively balances the

satisfy the necessary elements of civil commitment if the standard is beyond a reasonable doubt. Id at $428-29$.

110 Id at 431. The Bail Reform Act (see note 96) is also the result of balancing societal interests with those of the defendant. In the following passage, Congress explains how it designed the act to be sensitive to these concerns:

While a deprivation of liberty of up to ten days is a serious matter, it must be balanced against the fact that the defendant has been arrested based on probable cause to believe that he has committed a crime, the fact that he is either already on conditional release ... or he is not in conformity with the immigration laws, and the fact that the court must find that he may flee or pose a danger to any other person or the community if released. On balance the Committee concluded that a detention of up to ten days in those circumstances is warranted and is in the interests of justice.

Comprehensive Crime Control Act, S Rep No 98-225, 98th Cong, 2d Sess 17 (1988). As noted, Congress adopted a clear and convincing standard for such determinations.

11 A longer sentence does increase the accompanying stigma as well. The dissent in McMillan sought to adopt the test that whenever a factor resulted in imposing a special stigma or special punishment it should be subject to a higher burden of proof. Moreover, the risk in the Guidelines cases may be more severe than the risk in McMillan, because of the lack of judicial discretion in the former. The Court stated in Addington, "[i]n cases involving individual rights, whether criminal or civil, "[t]he standard of proof [at a minimum] reflects the value society places on individual liberty." " 441 US at 425 (citations omitted). 112 See Section II.B. 
interests of the defendant against the relevant governmental concerns.

\section{CONCLUSION}

Under the Sentencing Guidelines, a judge must consider actions of the defendant for which the defendant was not convicted or charged but which can result in a longer sentence. While the Guidelines are silent on the standard of proof for such actions, courts have applied a preponderance of the evidence standard. Preponderance, however, may violate due process. The factors noted by the Supreme Court in McMillan suggest that under the Due Process Clause, a standard greater than preponderance might be required. The Court's due process balancing approach suggests that the appropriate standard is clear and convincing evidence.

The judge's decisions at sentencing do not determine guilt but do have a substantial effect on the punishment imposed. A clear and convincing standard uniquely balances the competing values of the defendant's interest with the fact that the defendant has been proven guilty. 
$-$ 